\title{
NOTES ON PANTOPODA
}

(With two plates)

(Received 18/6/63)

Frida Zilberberg

In material from Trindade Is. $\left(20^{\circ} 30^{\prime} \mathrm{S}-29^{\circ} 22^{\prime} \mathrm{W}\right)$ specimens belonging to the genus Rhynchothorax Costa 1861 and to the genus Anoplodactylus Wilson 1878 were found. Marcus (1940) does not mention the genus Rhynchothorax from Brazilian waters, only from the Magelanic District and confined to particular biotops.

Specimens of Anoplodactylus are also mentioned by Marcus as Halosoma robustum (Dohrn) 1881.

\section{Genus RHYNCHOTHORAX Costa 1861}

Distribution - Atlantic Ocean (Trindade Is.) and Mediterranean Sea (Capri): R. mediterraneus Costa 1861; Pacific Ocean (California): R. philopsammum Hedgpeth 1951; Antarctic (Ross Sea, Magelanic District): R. australis Hodgson 1907.

\section{Rhynchothorax mediterraneus Costa 1861}

(Figs. 1-4)

MATERIAL - Three imature specimens in a sequence of developmental stages which are hereonward indicated as specimen no. 1 the youngest, specimen no. 2 the intermediate and specimen no. 3 , the more developed one.

DESCRIPTION - Trunk compact, youngest specimens unsegmented (Fig. 2). It is known that segmentation exists in very young specimens of other species of Pantopoda, its absence in

Publ. n 184 do Inst. Ocean. da USP. 
specimen no. 1 may be due to the tissues being very thin or to fixation soon after a moult (Marcus 1940, p. 71). The first and second segments are separated, the third and fourth united. All specimens have dorsal tubercles on the posterior margin of each trunk segment. The tubercles differ in size and number of spines and bristles; they present a distal thick spine on specimen no. 1 and sparse ones on the others. The anterior tubercle is the longest in all specimens.

The youngest specimen is the smallest, the two others almost equal in size; but specimen no. 3 is wider.

Integument has round or pointed trunk tubercles and warts, almost imperceptible on specimen no. 1 and probably become more conspicuous as development proceeds.

Proboscis oval shaped, tapering from base to tip, inserted anteriorly to the eye tubercle near the palps and with a dorsal wart on specimens no. 1 and 2 (Fig. $2 \mathrm{~b}$ ).

Eye tubercle truncated cone-shaped in the two younger specimens (Fig. 2d). Dorsally to the insertion there is a thick wart and two little warts posteriorly. Spur-shaped in specimen no. 3, it has half the length of the proboscis; it is projected forwards, inserted near the palps and shows little posterior warts and a large anterior one.

Eyes could not be found.

Lateral processes similar to those of the adult, wider than long, the former being larger than the others. The V-shaped gap between the processes is narrower on the base enlarging distally.

No tubercles present in the lateral processes in specimen no. 1, only one on the first pair of processes in specimen no. 2 and tubercles are present in all processes except in the third pair of specimen no. 3 .

Chelifores absent in all specimens.

Palps three jointed in the youngest specimen (Fig. 2), the basal one is the largest, the second and third follow in size, the third shows some bristles. Specimen no. 2 has four distinct joints; the lateral processes have a constriction at the palps level, probably the anlage of a new joint (Fig. 3b). The first joint is the longest followed by the second, third and fourth. Specimen no. 3 has five-jointed palps, the second joint is the largest followed by the third, first, fourth and fifth. Warts of considerable size turned centralwards occur on the first and second palp-joints, there is 
a spine also turned centralwards on the third joint and a great number of bristles on the last one. This joint has only few small bristles in the younger specimens.

Ovigers - No vestige of ovigers occur in the youngest specimen, in specimen no. 2 a protuberance is present where the ovigers will develop (Fig. 3a), and in the most developed specimen a tenjointed oviger with a terminal claw ventrally placed behind the insertion of the palps. The first joint is the smallest, basally enlarged; the second is approximately equal to the seventh; the third is as long as the eigth, ninth and tenth, distally as wide as the second; the fourth, is the largest, distally wider; the fifth is approximately as long as the sixth but not so wide, it has an external spine, near the middle of the seventh, eigth and ninth joints there is a wart with a large strong spine turned inwards, distally to it four to five strong little spines are present. On the seventh and eigth joints a little spine near the large one springs from the wart, it is apparently absent on the ninth joint. There are two strong spines on the base of the terminal joint and distally to them there is a longitudinal groove with denticulated borders which extends to the base of the terminal claw.

Ambulatory legs increase in length with development. The fourth pair of specimen no. 1 does not have all the joints and the proportions between those present is different (Fig. 2a); propodus is longer than in the other pairs and tarsus is absent; the size of the remaining legs differ proportionally from that of the adult. In specimens no. 2 and 3 the proportions between the joints approximate that of the adults being nearly (specimen no. 2) or quite (specimen no. 3) the definitive.

Coxae approximately of equal length, the first wider than the others with a distal tubercle turned back and outwards. In specimen no. 1 first coxae bears two lateral tubercles, one anterior, the other posterior. Femur narrower than the third coxae, but wider than the following joints, generally it has one or two spines. First tibiae longer than the second, provided with a few bristles and a dorsal spine. In specimen no. 1 this spine is longer than the entire joint. Tarsus small, in specimen no. 3 it shows two ventral spines near the insertion. Propodus approximately: as long as the first tibiae has about six spines on the sole and some dorsal ones near the insertion of the dactylus and two dorsal spines in specimen no. 3. Dactylus has one third of the propodus length.

Digestive tract does not extend beyond first coxae.

Exit of genital apparatus and cement!glands not observed. 
Measurements (in micra)

\begin{tabular}{|c|c|c|c|}
\hline$\ldots \ldots \ldots \ldots \ldots \ldots \ldots$ & No. 3 & No. 2 & No. 1 \\
\hline Total length $\ldots \ldots \ldots \ldots \ldots \ldots \ldots$ & 1,290 & 1,215 & 660 \\
\hline Trunk maximal width $\ldots \ldots \ldots \ldots \ldots$ & 495 & 390 & 225 \\
\hline Trunk length $\ldots \ldots \ldots \ldots \ldots \ldots \ldots$ & 690 & 705 & 375 \\
\hline Trunk $1^{\text {st }}$ joint $\ldots \ldots \ldots \ldots \ldots \ldots$ & 300 & 300 & 一 \\
\hline Trunk $2^{\text {nd }}$ joint $\ldots \ldots \ldots \ldots \ldots \ldots$ & 172.5 & 180 & 一 \\
\hline $3^{\text {rd }}$ and $4^{\text {th }}$ joints $\ldots \ldots \ldots \ldots \ldots \ldots$ & 210 & 225 & - \\
\hline Proboscis length $\ldots \ldots \ldots \ldots \ldots \ldots$ & 450 & 382.5 & 180 \\
\hline Proboscis width $\ldots \ldots \ldots \ldots \ldots \ldots$ & 300 & 210 & 105 \\
\hline Eye tubercle $\ldots \ldots \ldots \ldots \ldots \ldots \ldots$ & 225 & 105 & 90 \\
\hline Abdomen length $\ldots \ldots \ldots \ldots \ldots \ldots$ & 180 & 135 & 90 \\
\hline Abdomen width $\ldots \ldots \ldots \ldots \ldots \ldots$ & 75 & 45 & 30 \\
\hline Leg measured $\ldots \ldots \ldots \ldots \ldots \ldots \ldots$ & $2^{\text {nd }}$ & $1^{\text {st }}$ & $1^{\text {st }}$ \\
\hline Coxae $1 \ldots \ldots \ldots \ldots \ldots \ldots \ldots \ldots$ & 90 & 75 & 45 \\
\hline Coxae $2 \ldots \ldots \ldots \ldots \ldots \ldots \ldots \ldots \ldots \ldots$ & 90 & 75 & 45 \\
\hline Coxae $3 \ldots \ldots \ldots \ldots \ldots \ldots \ldots \ldots \ldots$ & 75 & 75 & 37.5 \\
\hline Femur $\quad \ldots \ldots \ldots \ldots \ldots \ldots \ldots \ldots \ldots \ldots$ & 255 & 195 & 135 \\
\hline Tibia $1 \quad \ldots \ldots \ldots \ldots \ldots \ldots \ldots \ldots \ldots$ & 240 & 225 & 150 \\
\hline Tibia $2 \quad \ldots \ldots \ldots \ldots \ldots \ldots \ldots \ldots \ldots$ & 180 & 165 & 135 \\
\hline Tarsus $\quad \ldots \ldots \ldots \ldots \ldots \ldots \ldots \ldots \ldots$ & 60 & 37.5 & 30 \\
\hline Propodus $\quad \ldots \ldots \ldots \ldots \ldots \ldots \ldots \ldots$ & 210 & 150 & 120 \\
\hline Dactylus $\ldots \ldots \ldots \ldots \ldots \ldots \ldots \ldots \ldots$ & 90 & 60 & 37.5 \\
\hline Palps $\ldots \ldots \ldots \ldots \ldots \ldots \ldots \ldots \ldots \ldots \ldots \ldots$ & 660 & 465 & 210 \\
\hline $\begin{array}{ll}\text { Oviger joints } & 1-2 \text { (not measured) } \\
& 8-52.5,9-60,10-45\end{array}$ & $-135,4-75$, & $5-105,6-75$ & $7-60$, \\
\hline
\end{tabular}

OCCURRENCE - Trindade Is. (20 $30^{\prime}$ 'S- $\left.29^{\circ} 22^{\prime} \mathrm{W}\right)$ collected by the late Director of Instituto Oceanográfico: W. Besnard (MayJune 1950). depth.

FURTHER DISTRIBUTION - Mediterranean Sea (Capri), $90 \mathrm{~m}$

ECOLOGICAL NOTES - The specimens were dredged from 5070 m depth together with Lithothamnion with high organic content (Besnard 1951, p. 43) and rich in boring sipunculids and polychaets. Trindade Isle is under the influence of the Brazil Current waters, the temperature is higher than $25^{\circ} \mathrm{C}$ and salinity higher than $37 \%$ (Machado 1951, p. 106).

Discussion - Dohrn (1881, p. 211-215) described the adult and a post larval stage of this species, which differs in several details from the present specimens. However I do not consider these morphological differences to be of specific rank but rather as due to stage of development. 
Dohrn's immature specimen is an intermediate stage of development between the two younger ones and the most developed specimen described here, a fact which may be confirmed by the number of joints of the oviger.

The main difference between the present specimens and Dohrn's is the absence of eyes. In other species of Pantopoda eyes when present are evident since the protonymphon (Dawydoff 1928 , p. 514); therefore their absence in the specimens here described seems strange. Helfer \& Schlottke (1935, p. 105) mention blind individuals occurring in eyed species.

Since $R$. philopsammum Hedgpeth 1951, a blind species inhabiting the endopsammon, was considered well adapted to its environment (Delamare Deboutteville 1960, p. 264) it is also possible that the present specimens represent a blind variety of $R$. mediterraneus, a fact which will be proved only when abundant material is available.

Dohrn (op. cit., p. 210) describes the palps as 8-jointed but only five joints may be seen in his figures (pl. XVII, figs. 1-2). My specimen no. 3 has also 5 joints. The younger specimens show a smaller number which suggests that the joints are acquired on successive moults, a fact known for Arthropoda in general (Dawidoff 1928, p. 440).

The tubercle present in the proboscis of specimens no. 1 and 2 is absent in Dohrn's specimens, a fact that suggests that it is a larval character.

\title{
Genus ANOPLODACTYLUS Wilson 1878
}

\section{Distribution - Chiefly in tropical waters.}

\author{
Anopladactylus robustus (Dohrn) 1881
}

(Figs. 5-7)

Phoxichilidium robustum Dohrn 1881 p. 188, pl. XII, fig. 13-8;

Halosoma robustum Marcus 1940, p. 68, fig. 8 a-c;

Anoplodactylus robustus Stock 1955, p. 237, fig. 12 b, c

Material - Three specimens belonging to the collections of the Hydrobiology Section of Oswaldo Cruz Institute (Rio de Janeiro) labeled no. $2764 *$.

* Thanks are due to Prof. Lejeune de Oliveira for the loan of the specimens. 
DESCRIPTION - Trunk shield-like-shaped, unsegmented. Lateral processes a little divergent but basally contiguous, medium dorsal tubercles present distally. Eye tubercle pointed, placed behind the distal border of the first segment. Proboscis oval-shaped. Abdomen small. Chelifores longer than the proboscis. Palps absent. Ovigers show six joints. The third joint has a pseudosegmentary constriction; the terminal joint shows 3 to 4 pairs of bristles distributed along a longitudinal series (Fig. 6). Ambulatory legs strong, the first coxae with dorso-lateral tubercles. Propodus of some legs have a cutting edge all along the sole. Auxiliary claws are absent. Exit of cement glands on a dorsal protuberance placed on the femur of all legs (Fig. 7a).

Measurements of one specimen (in micra):

Total length -990

Maximal width of the trunk -600

Proboscis - 390

Eye tubercle - 180

Abdomen - 150

Ambulatory leg:

Coxae $1-150$

Coxae $2-245$

Coxae $3-210$

Femur - 450

Tibia $1-390$

Tibia $2-360$

Tarsus -75

Propodus - 315

Dactylus — 195

Oviger joints 1-120, 2-210, 3-240, 4-165, 5-165, 6-75.

OCCURRENCE - $\left(20^{\circ} 29.2^{\prime} \mathrm{S}-29^{\circ} 20.2^{\prime} \mathrm{W}\right)$ Trindade Is., sample 22 taken during the cruise of "Baependi" and "Vega" (Oliveira 1951, p. 450$) ; 40 \mathrm{~m}$ depth. Collected by Prof. Lejeune de Oliveira.

FURTHER DISTRIBUtion - Atlantic Ocean (Brazil: Bay of Santos; Belgian Congo: Banana?); Mediterranean Sea (Naples, Banyuls).

Discussion - The present specimens diverge from Marcus' description of Halosoma robustum (1940, p. 68) in the absence of segmentation of the trunk, number of joints of the ovigers, and in having the exit of the cement glands on a dorsal protuberance 
of the femur. Mediterranean specimens also showed no segmentation (Dohrn 1881, p. 188).

According to Marcus (loc. cit.) the presence of trunk segment sutures depends on the state of the integument which is conditioned to age but more exactly on the time elasped since the last moult. Therefore this very variable character has little taxonomic value.

Other differences appear to be only due to individual variation. The number of joints of the oviger, the protuberant exit of cement glands present on the femur of all legs, the projected anterior part of the trunk lead me, following Stock (1954, p. 70 and ant.) to consider genus Halosoma Cole 1904 as a synonym of Anoplodactylus Wilson 1878.

\section{ACKNOWLEDGEMENTS}

I wish to express my gratitude to Prof. Dr. E. Marcus for reading the manuscript and for helpful suggestions; to Dr. Marta Vannucci for the very stimulating discussions during the elaboration of this paper and for the most valuable improvements, and to Dr. Liliana Forneris for suggestions and criticism. Mrs. M. C. Catunda helped in the English text.

\section{R E S U M O}

Rhynchothorax mediterraneus Costa 1861 e Anoplodactylus robustus (Dohrn) 1881 dragados em fundo de Lithothamnion na região da Ilha da Trindade $\left(20^{\circ} 30^{\prime} \mathrm{S}-29^{\circ} 22^{\prime} \mathrm{W}\right)$, são descritos.

Três espécimes imaturos, em seqüência de desenvolvimento, pertencem ao gênero Rhynchothorax Costa 1861, pela primeira vez assinalado em águas brasileiras.

Espécime mais jovem - apresenta tubérculo ocular semelhante a cone truncado, giba dorsal na proboscis, palpo sem o número definitivo de artículos, ovígero ausente, quarto par de pernas ambulatórias sem tarso. Comprimento: 660 micra.

Espécime intermediário - ovigero presente, representado por um botão; quarto par de pernas ambulatórias com todos os artículos. Comprimento: 1.215 micra.

Espécime mais desenvolvido - semelhante ao adulto descrito por Dohrn (1881, p. 211-215), apresenta tubérculo ocular em forma de espora, giba dorsal na proboscis ausente, palpo com o número definitivo de artículos; ovígero 10-articulado; gônadas e glândulas de cimento ausentes. Comprimento: 1.290 micra.

A ausência de olhos nos exemplares sugere a possibilidade dêste material representar variedade cega de Rhynchothorax mediterraneus Costa 1861.

Anoplodactylus robustus (Dohrn) 1881, descrito anteriormente como $\mathrm{Ha}$ losoma robustus (Marcus 1940, p. 68), diverge dêste último na ausência de segmentação, ovígero 6-articulado, desembocadura das glândulas argamassadoras em protuberância dorsal localizada no fêmur de tôdas as patas ambulatórias. Caracteres anatômicos fundamentam a inclusão da espécie em Anoplodactylus (Stock 1954, p. 70). 


\section{PLATE I}

Rhynchothorax mediterraneus Costa 1861

Fig. 1 - Profile view of specimen no. 2 .

Fig. 2 - Dorsal view of specimen no. 1 .

a) Tarsus and propodus not separated by suture.

b) Wart on proboscis.

c) Dorsal tubercles with terminal spines.

d) Eye tubercle truncated-cone-shaped.

Fig. 3 - Ventral view of specimen no. 2 .

a) Proeminences of the ovigers.

b) Strangling on palps insertion.

Fig. 4 - Oviger of specimen no. 3 . 

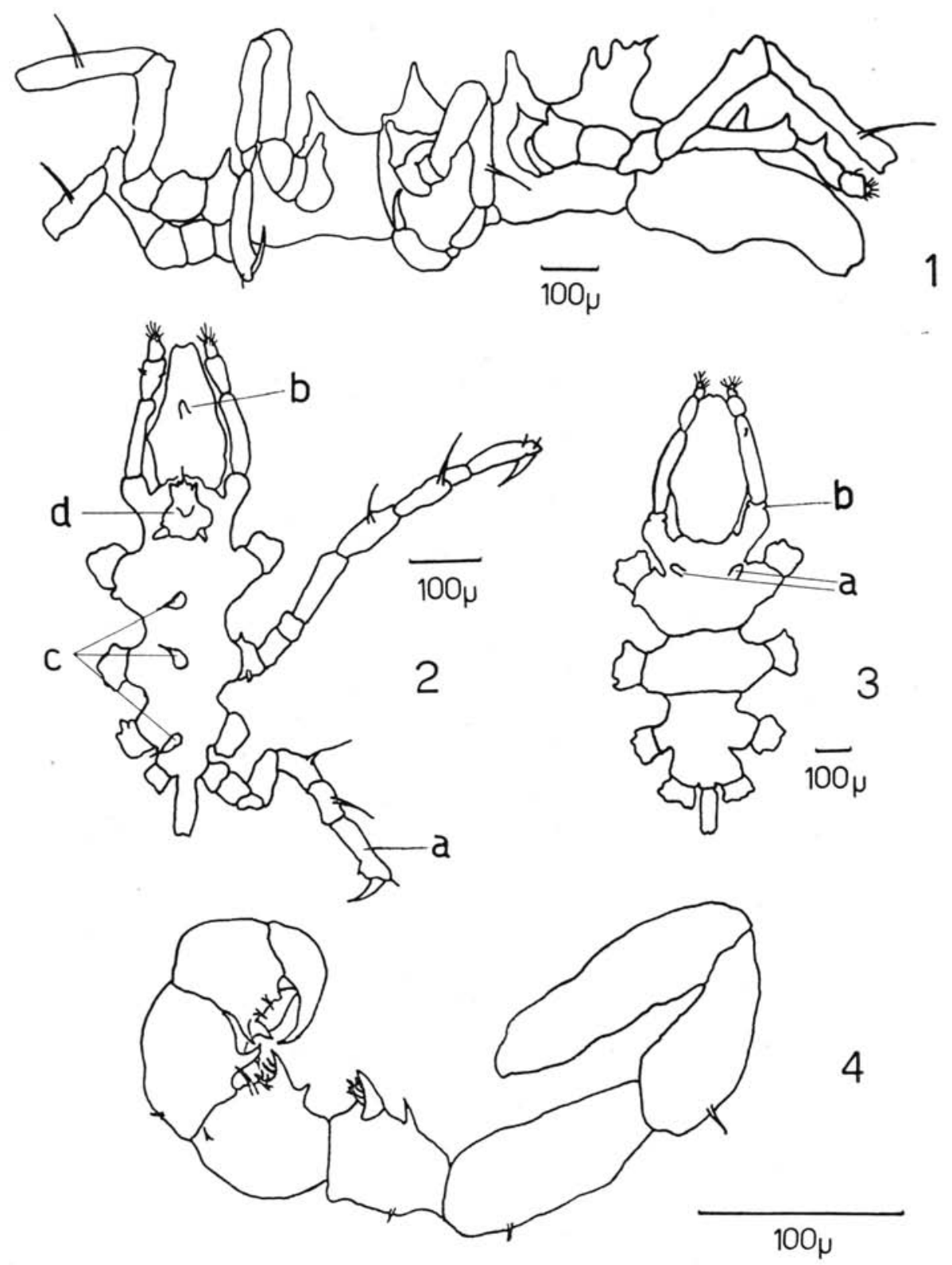
PLATE II

Anophodactylus robustus (Dohrn) 1881

Fig. 5 - Dorsal view.

Fig. 6 - Oviger.

Fig. 7 - Second ambulatory leg.

a) Exit of cement gland. 


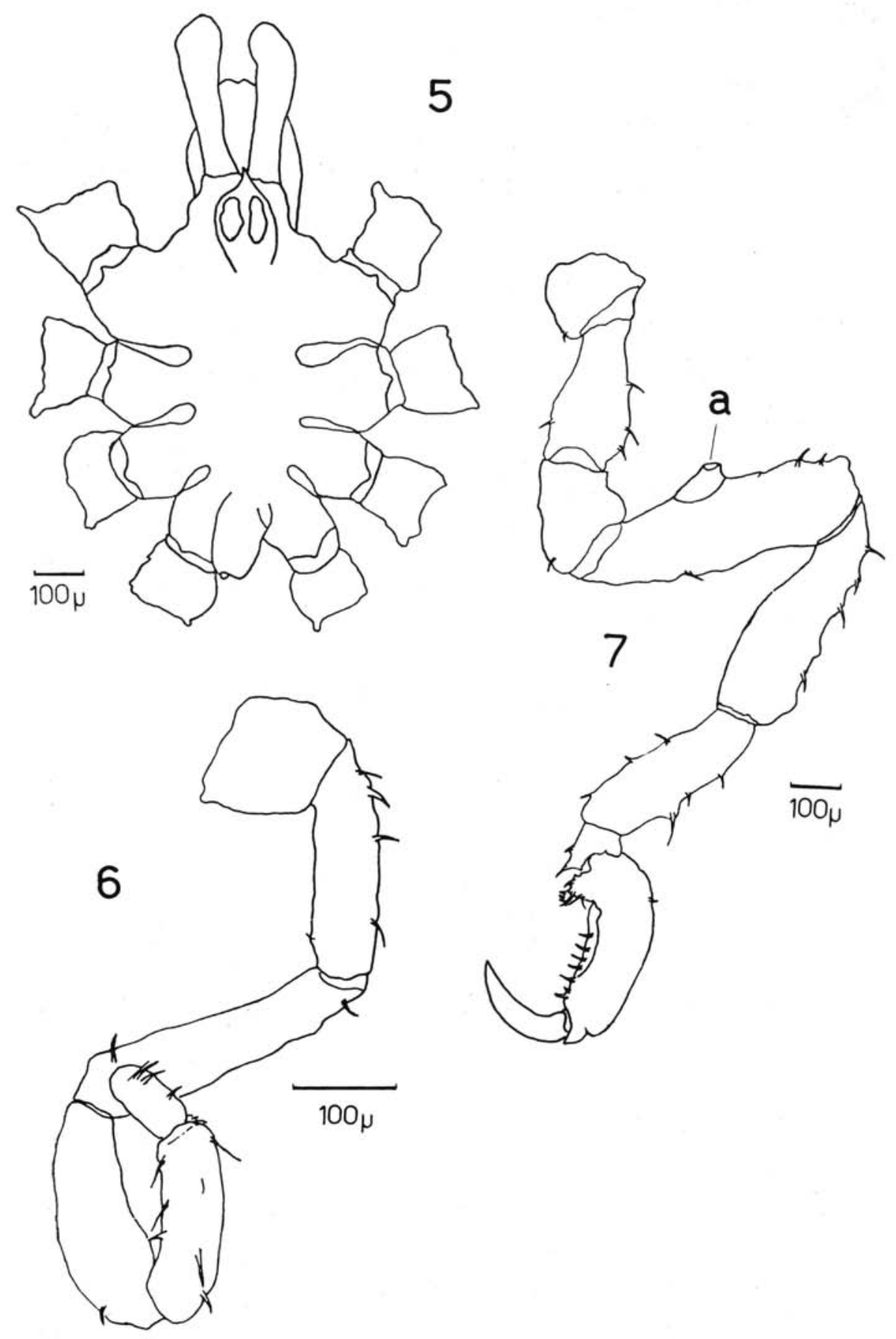




\section{R E F E R E C E S}

BESNARD, W.

1951. Resultados científicos do cruzeiro do "Baependi" e do "Vega" à Ilha da Trindade. Contribuição para o conhecimento da plataforma insular da I. da Trindade. Bol. Inst. Paul. Ocean., vol. 2, n. $^{\circ} 2$, p. $37-53$.

DAWYDOFF, C.

1928. Traité d'embryologie comparée des invertébrés. Paris, Masson. xiv +930 p.

Delamare Deboutteville, C.

1960. Biologie des eaux souterraines littorales et continentales. Suppl. n. 9 a Vie et Milieu, 740 p. Lab. Arago.

DOHRN, A.

1881. Die Pantopoden des Golfes von Neapel und der angrenzenden Meeres-Abschnitte. Fauna des Golfes von Neapel, Mon. 3, 252 p. 18 pls.

Hedgpeth, J. W.

1951. Pycnogonids from Dillon Beach and vicinity, California, with description of two new species. Wassmann Jour. Biol., vol. 9, n. ${ }^{\circ} 1$, p. $105-117$.

Helfer, H. \& Schlottke, E.

1935. Pantopoda. Bronn Klass. \& Ordn. Tierr., vol. 5, Abtlg. 4, p. 1-134. Leipzig.

HodGson, T. V.

1907. Pycnogonida. Nat. Ant. Exp., 1901-1904, Nat. Hist., V. 3, 72 p. 10 pls.

Machado, L. DE B.

1951. Resultados científicos do cruzeiro do "Baependi" e do "Vega" à Ilha da Trindade. Oceanografia Física. Contribuição para o conhecimento das características físicas e químicas das águas. Bol. Inst. Paul. Ocean., vol. 2, n. ${ }^{\circ}$ 2, p. 73-118.

Marcus, E.

1940. Os Pantopoda brasileiros e os demais sul-americanos. Bol. Fac. Fil. Ciên. Letr. Univ. S. Paulo, Zool. n. ${ }^{\circ} 4$, p. 3-179, 17 pls.

Oliveira, L. P. H. DE

1951. Nota prévia sôbre a fauna e flora marinha bentônica da Ilha da Trindade. Mem. Inst. Oswaldo Cruz, vol. 49, p. 443-456.

Sтоск, J. H.

1954. Pycnogonida from Indo West Pacific Australian and New Zealand waters. Vidensk. Medded. Dansk. Naturh., Foren., vol. 116, p. 1-168, figs. 1-81.

1955. Pycnogonida from the West Indies, Central America and the Pacific coast of North America. Vidensk. Medded. Dansk. Naturh. Foren., vol. 117, p. 209-266, figs. 1-26. 